\title{
Antimicrobial Activity and Degradation of Superhydrophobic Magnesium Substrates in Bacterial Media
}

\author{
Alexandre M. Emelyanenko ${ }^{1, *}{ }^{\circledR}$, Valery V. Kaminsky ${ }^{2,3}$, Ivan S. Pytskii ${ }^{1}{ }^{1}$, Kirill A. Emelyanenko ${ }^{1}$, \\ Alexander G. Domantovsky ${ }^{1}$, Elizaveta V. Chulkova ${ }^{1}$, Andrei A. Shiryaev ${ }^{1} \mathbb{D}$, Andrei V. Aleshkin ${ }^{2}$ \\ and Ludmila B. Boinovich ${ }^{1, *(D)}$ \\ 1 A.N. Frumkin Institute of Physical Chemistry and Electrochemistry, Leninsky Prospect 31 bldg. 4, \\ 119071 Moscow, Russia; ivanpic4586@gmail.com (I.S.P.); emelyanenko.kirill@gmail.com (K.A.E.); \\ doman-alex@yandex.ru (A.G.D.); chulkova_liza@mail.ru (E.V.C.); a_shiryaev@mail.ru (A.A.S.) \\ 2 G.N. Gabrichevsky Research Institute for Epidemiology and Microbiology, 10 Admiral Makarov St., \\ 125212 Moscow, Russia; kaminskyvalery86@gmail.com (V.V.K.); andreialeshkin@gmail.com (A.V.A.) \\ 3 Federal State Budgetary Institution Russian Scientific Center of Roentgenoradiology (RSCRR) of the Ministry \\ of Healthcare of the Russian Federation, 117997 Moscow, Russia \\ * Correspondence: ame@phyche.ac.ru (A.M.E.); boinovich@mail.ru (L.B.B.); Tel.: +7-495-955-4625 (L.B.B.)
}

\section{check for}

updates

Citation: Emelyanenko, A.M.; Kaminsky, V.V.; Pytskii, I.S.;

Emelyanenko, K.A.; Domantovsky,

A.G.; Chulkova, E.V.; Shiryaev, A.A.;

Aleshkin, A.V.; Boinovich, L.B.

Antimicrobial Activity and

Degradation of Superhydrophobic

Magnesium Substrates in Bacterial

Media. Metals 2021, 11, 1100.

https://doi.org/10.3390/met11071100

Academic Editor: Petra Maier

Received: 20 June 2021

Accepted: 8 July 2021

Published: 10 July 2021

Publisher's Note: MDPI stays neutral with regard to jurisdictional claims in published maps and institutional affiliations.

Copyright: (c) 2021 by the authors. Licensee MDPI, Basel, Switzerland. This article is an open access article distributed under the terms and conditions of the Creative Commons Attribution (CC BY) license (https:// creativecommons.org/licenses/by/ $4.0 /)$.

\begin{abstract}
The interest in magnesium-based materials is promoted by their biocompatibility, their bioresorbability, and their recently discovered antibacterial potential. Until now, the widespread use of magnesium alloys in different corrosive environments was inhibited by their weakly controllable degradation rate and poorly understood microbiologically induced corrosion behavior. To better understand the degradation and usability of magnesium-based alloys, in this study we have fabricated superhydrophobic coatings on a magnesium-based alloy, and analyzed the behavior of this alloy in bacterial dispersions of Pseudomonas aeruginosa and Klebsiella pneumoniae cells in phosphate-buffered saline. It was shown that the immersion of such coatings in bacterial dispersions causes notable changes in the morphology of the samples, dependent on the bacterial dispersion composition and the type of bacterial strain. The interaction of the superhydrophobic coatings with the bacterial dispersion caused the formation of biofilms and sodium polyphosphate films, which provided enhanced barrier properties in magnesium dissolution and hence in dispersion medium alkalization, eventually leading to the inhibition of magnesium substrate degradation. The electrochemical data obtained for superhydrophobic samples in continuous contact with corrosive bacterial dispersions for $48 \mathrm{~h}$ indicated a high level of anticorrosion protection.
\end{abstract}

Keywords: superhydrophobicity; magnesium; biocorrosion; biofilm; bacterial dispersion; biodegradation

\section{Introduction}

In recent years, the interest of the scientific community in studies of the behavior of magnesium and its alloys in various environments, and in the development of new materials based on magnesium for biomedical purposes, has sharply increased [1]. This interest is promoted by the biocompatibility of magnesium, the possibility of its use for biodegradable devices and in implantology, and, finally, by the attractive mechanical properties of magnesium alloys. Additionally, the most highly demanded property of magnesium-based materials is their antibacterial potential, since infections are one of the most unfavorable complications associated with the implantation of any device. At the same time, until recently, the widespread use of magnesium alloys in different corrosive environments, including physiological liquids, was inhibited by its high degradation, leading to the release of hydrogen and an increase in the $\mathrm{pH}$ of the liquid medium. In addition, the microbiologically induced corrosion of metals usually contributes to their destruction. The rapid and weakly controllable degradation rate of magnesium and its alloys greatly hampers the clinical use of these materials. Therefore, significant efforts are currently 
being made in analyzing the mechanism of antibacterial activity of magnesium-based alloys [2-5], and finding the ways to slow down the rate of degradation. Among the most promising options for protection against degradation are magnesium alloying [6-8], the use of particles of magnesium or magnesium alloys as fillers for polymer matrices [9-11], deposition of protective layers on magnesium alloy substrates [12], and the use of treatments of magnesium alloys, leading to a superhydrophobic state in the surface [13-20].

Recently, we have shown [17] that the appropriate selection of a laser treatment regime for obtaining the desired texture and chemical composition of the surface layer makes it possible to create a superhydrophobic coating on a magnesium alloy that exhibits satisfactory corrosion resistance even after prolonged immersion in a $0.5 \mathrm{M}$ sodium chloride solution. In this work, we investigate the degradation and anticorrosive properties of fabricated superhydrophobic coatings under conditions of microbiological corrosion when immersed in bacterial dispersions of bacteria cells Pseudomonas aeruginosa and Klebsiella pneumoniae in phosphate-buffered saline.

\section{Materials and Methods}

\subsection{Sample Preparation}

We used magnesium alloy MA8 with the chemical composition (in weight \%) Mn 1.65, Ce 0.25, Fe 0.05, Si 0.05, Ni 0.007, Al 0.1, Cu 0.05, Be 0.002, Zn 0.04, Mg balance, to fabricate superhydrophobic samples for the studies described in this paper. Flat sheets with a thickness of $2 \mathrm{~mm}$ were cut into samples with a size of $20 \times 20 \mathrm{~mm}^{2}$. To impart the superhydrophobic state onto the samples' surfaces, we used a strategy based on attaining hierarhical roughness on the surface, as achieved by laser texturing, and on surface energy reduction via deposition of a hydrophobic agent. Surface texturing was performed using nanosecond laser treatment through the laser processing regimes described in our recent paper [17]. The selection of the regimes was based on the best corrosion protection properties of samples during prolonged contact with $0.5 \mathrm{M} \mathrm{NaCl}$ aqueous solution. To perform the laser processing of the samples, we used an Argent-M laser system (LLC "LTC", St. Petersburg, Russia) with an IR ytterbium fiber laser (wavelength of $1.064 \mu \mathrm{m}$, nominal power $20 \mathrm{~W}$, a beam waist of $40 \mu \mathrm{m}$ ), and a RAYLASE MS10 2-axis laser beam deflection unit (RAYLASE $\mathrm{GmbH}$, Wessling, Germany). The laser beam used for the raster scanning of the sample was characterized by the following parameters: fluence $1.5 \mathrm{~J} / \mathrm{cm}^{2}$, line density $400 \mathrm{~mm}^{-1}$, linear scanning rate $100 \mathrm{~mm} / \mathrm{s}$, pulse duration $4 \mathrm{~ns}$, repetition rate $1000 \mathrm{kHz}$. Laser treatment was performed at a temperature of $20-25{ }^{\circ} \mathrm{C}$ and relative humidity of $40-50 \%$. After the laser treatment, the samples were thoroughly washed with deionized water to remove surface micro- and nanoparticles that were weakly adhering to the sample.

To attain a superhydrophobic state on the surface, the laser-treated samples were first subjected for $1 \mathrm{~h}$ to ozone-assisted UV irradiation, and then hydrophobized by exposure to saturated vapors of methoxy- $\{3-[(2,2,3,3,4,4,5,5,6,6,7,7,8,8,8$-pentadecafluorooctyl)oxy]propyl\}-silane in a sealed vessel for $1 \mathrm{~h}$ at $105^{\circ} \mathrm{C}$, and dried for $1 \mathrm{~h}$ in an oven at $150{ }^{\circ} \mathrm{C}$. The obtained surfaces had water contact angles of more than $170{ }^{\circ} \mathrm{C}$ and roll-off angles below $3^{\circ}$. The details of the hydrophobization procedure, with a substantiation of each stage necessary to derive a superhydrophobic state with extremely high contact angle, low roll-off angle, and satisfactory durability, are discussed in [21].

\subsection{Analysis of Bactericidal Properties of the Superhydrophobic Magnesium Substrates}

In this study, the bactericidal activity of superhydrophobic magnesium alloy substrates was studied with respect to two pathogenic strains, Pseudomonas aeruginosa (P. Aeruginosa) and Klebsiella pneumoniae B-811 (K. pneumoniae). The strains were obtained from the State Collection of Pathogenic Microorganisms and Cell Cultures (GKPM-Obolensk, Obolensk, Russia), registration numbers B-8050 for P. aeruginosa and B-7707 for K. pneumoniae. Phosph ate-buffered saline (PBS) purchased from VWR Life Science AMRESCO (Radnor, PA, USA) was used as a dispersion medium. This choice of dispersion medium is related to the recently detected significant effect of the nutrient dispersion medium on the corrosion activity of 
metallic surfaces immersed in bacterial dispersion, which in turn modulates the antibacterial properties $[22,23]$. Using PBS, which does not contain protein nutrients, precludes the disturbing influence of protein nutrients on the antibacterial efficiency of magnesium substrates. To prepare the bacterial suspensions, an overnight bacterial culture was introduced into the PBS and incubated for $18 \mathrm{~h}$ at $37^{\circ} \mathrm{C}$. For the experiments, dispersions of bacterial cells with an initial titer of $10^{7}-10^{8}$ colony-forming units (CFU) per $\mathrm{mL}$ were used.

To test the bactericidal properties with respect to planktonic forms of different strains, superhydrophobic plates were placed in a separate sterile cup for each strain, and $40 \mathrm{~mL}$ of the each bacterial suspension was poured into its corresponding cup. The cups were stored at room temperature for $48 \mathrm{~h}$. To evaluate the bactericidal action of the plates in contact with the dispersion, after a predefined time of contact, an assay of a bacterial suspension with a volume of $0.5 \mathrm{~mL}$ was taken from each cup. Ten-fold dilutions were prepared, then $0.1 \mathrm{~mL}$ was taken from each dilution and evenly distributed over the surface of Müller-Hinton agar in Petri dishes. After incubation at $37^{\circ} \mathrm{C}$ for $24 \mathrm{~h}$, the bacterial titer was determined by counting the formed colonies. To quantify the effect of contact between the bacterial suspension and the superhydrophobic MA8 plate, for each strain and each contact duration, the obtained titer was normalized to the initial titer in the dispersion.

Additionally, for each strain and each contact duration, a second assay $(1 \mathrm{~mL})$ was used for the determination of magnesium egress into PBS, as described below.

\subsection{Determination of the Concentration of $\mathrm{Mg}^{2+}$ in a Dispersion Medium}

The assay containing $1 \mathrm{~mL}$ of bacterial dispersion was poured into an Eppendorf tube and centrifuged at 14,000 rpm for $10 \mathrm{~min}$. The liquid phase after centrifugation was used to determine magnesium content in the PBS via mass spectroscopy analysis, using the inductively coupled plasma mass spectrometer (ICP-MS) Agilent 7500CE (Agilent Technologies, Santa Clara, CA, USA).

Concentrated nitric acid (65 wt.\%) was added to each sample in order to obtain a $0.01 \mathrm{M}$ solution. Then, the digestion of samples was carried out at $60{ }^{\circ} \mathrm{C}$ for $40 \mathrm{~min}$. The nitric acid used in the digestion was of high purity (Sigma-Aldrich, Burlington, VT, USA). All digestion samples were prepared in a laminar flow cabinet. The resulting solution was injected directly into the instrument. Laboratory blank samples were also analyzed via the same digestion method. The average magnesium concentration in blank samples was then subtracted from the measured concentration in each digest to give the final reported concentration of that element. Each sample was analyzed 3 times in order to assess possible drift effects. Standard solutions for calibration with respect to magnesium were prepared by diluting multi-element stock solutions (Agilent Technologies multi-element solution, $10 \mathrm{mg} / \mathrm{L})$ with Milli-Q water containing $0.6 \%(0.01 \mathrm{M})$ nitric acid. The calibration scale was from $1 \mu \mathrm{g} / \mathrm{L}$ to $1 \mathrm{mg} / \mathrm{L}, \mathrm{R}^{2}=0.999$.

\subsection{Characterization of Surface Morphology, Chemical and Phase Composition}

Phase analysis of the laser-treated samples was performed with the X-ray diffractometer Empyrean (Panalytical BV, Almelo, The Netherlands) using Ni-filtered Cu Ka1-radiation in standard Bragg-Brentano (reflection) geometry. The diffraction patterns of the as-treated samples were dominated by very strong reflections from the bulk Mg-alloy; the identification of phases in the surface layer was complicated by both the very small amount of material and the plausible texture effects, making interpretation difficult. Subsequently, material from the surface was collected by gentle mechanical scratching, thus minimizing the contribution of the bulk material and decreasing the influence of texture.

The morphology and the elemental composition of the samples were studied by fieldemission scanning electron microscopy and energy-dispersive X-ray spectroscopy (EDS) on an FIB-SEM Nvision 40 workstation (Zeiss, Oberkochen, Germany) equipped with an X-MAX energy-dispersive detector (Oxford Instruments, High Wycombe, UK). The SEM images were recorded in secondary electron detection mode at accelerating voltages of $2-5 \mathrm{kV}$. EDS microanalysis was performed at a $10 \mathrm{kV}$ accelerating voltage. 
The infrared spectra of the samples were investigated using the Fourier-transform infrared (FTIR) spectrometer Nicolet 6700 (Thermo Scientific, Waltham, MA, USA), with a specular apertured grazing angle (SAGA) accessory and a mercury cadmium telluride (MCT) detector cooled with liquid $\mathrm{N}_{2}$. The angle of incidence for SAGA was $80^{\circ}$, and the diameter of the circular sampling area was $8 \mathrm{~mm}$. The spectra were recorded at a resolution of $4 \mathrm{~cm}^{-1}$. All the spectra were derived from the result of an average of 128 scans.

\subsection{Characterization of Surface Wettability and $p H$ of the Dispersion Medium}

The measurement of $\mathrm{pH}$ in bacterial dispersions after a predefined time of contact between the superhydrophobic sample and the dispersion was performed using the microelectrode ESK-10614 (LLC Measuring Technology, Moscow, Russia).

The wettability of the coatings just before and after contact with the bacterial dispersions was characterized by measuring the contact and roll-off angles. Digital image processing of the sessile droplets and Laplace fit optimization for determining the droplet shape parameters were used to calculate the contact angles [24]. The roll-off angle of the sessile droplets was defined by gently tilting the substrate until the droplet started to roll over the surface. Both the contact angles and roll-off angles were measured for $15 \mu \mathrm{L}$ droplets at at least 10 different surface locations for each sample.

\subsection{Characterization of Electrochemical Properties of Surfaces after Contact with Bacterial Suspensions}

The electrochemical properties of the test surfaces were studied using an electrochemical workstation Elins P50x (Elins, Chernogolovka, Russia) equipped with a frequencyresponse analyzer (FRA $24 \mathrm{M}$ ) for electrochemical impedance spectroscopy measurements. The measurements were carried out at $25^{\circ} \mathrm{C}$ in a three-electrode cell (PAR K0235 (Princeton Applied Research, Oak Ridge, TN, USA)), with a $0.5 \mathrm{M} \mathrm{NaCl}$ aqueous solution as the electrolyte. A silver/silver chloride electrode $(\mathrm{Ag} / \mathrm{AgCl})$ filled with saturated $\mathrm{KCl}$ solution served as a reference electrode, and a Pt mesh served as a counter electrode.

To study the effect of the corrosion degradation of superhydrophobic samples in bacterial dispersions, the samples were immersed in the dispersion for up to $48 \mathrm{~h}$. The corrosion degradation was analyzed via the corrosion current and the impedance spectra. For the measurements, the sample was taken off the dispersion, rinsed with distilled water, and placed into the three-electrode electrochemical cell as a working electrode. The measurement of polarization curves was performed after $60 \mathrm{~min}$ of equilibration of the sample to a $0.5 \mathrm{M}$ sodium chloride aqueous solution. The potentiodynamic polarization curves were registered at a scan rate of $1 \mathrm{mV} / \mathrm{s}$ in the applied potential range of -150 to $+300 \mathrm{mV}$ (with respect to open circuit potential). The corrosion potential, $E_{c o r}$, and current, $J_{c o r}$, were derived from the potentiodynamic polarization curves after Tafel extrapolation.

A sinusoidal perturbation signal with an amplitude of $10 \mathrm{mV}$ (with respect to open circuit potential) was used for the electrochemical impedance spectroscopy measurements. Impedance spectra were acquired in the frequency range from $0.05 \mathrm{~Hz}$ to $100 \mathrm{kHz}$ via a logarithmic sweep (20 points per decade).

\section{Results and Discussion}

\subsection{Morphology and Wettability of Superhydrophobic Coating}

The as-fabricated superhydrophobic coating on the magnesium alloy MA8 is characterized by hierarchical roughness and a low surface energy, which resulted in an apparent contact angle of $171 \pm 1^{\circ}$ and roll-off angle of $3 \pm 1^{\circ}$. The analysis of the coating's behavior when in continuous contact with deinonized water showed the extremely low degradation of the superhydrophobic properties, with the maintenance of contact angles above $170^{\circ}$ and roll-off angles below $5^{\circ}$. The morphology of the textured surface of this coating before contact with the corrosive liquid medium is shown in Figure 1a,b. The immersion of this coating into the bacterial dispersions in PBS caused notable morphology changes (Figure 1c-h) because of the highly corrosive activity of the liquid medium. 


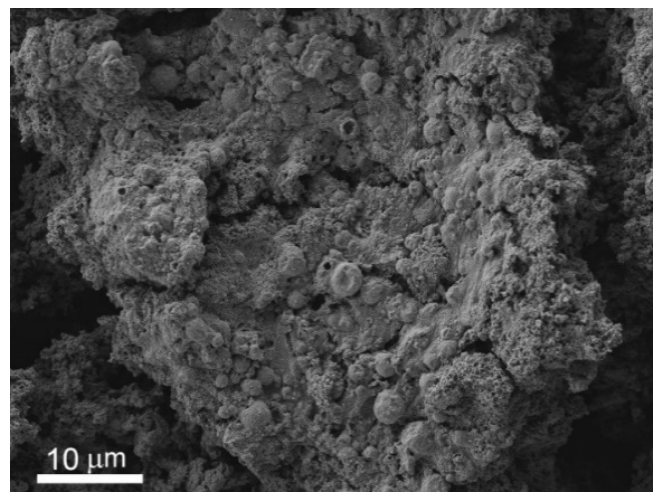

(a)

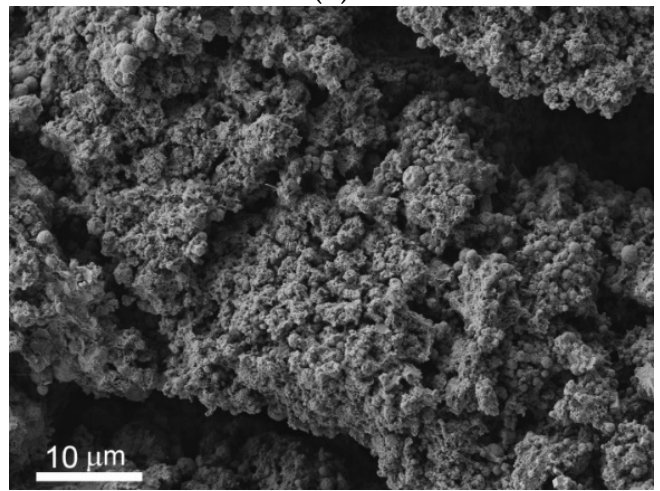

(c)

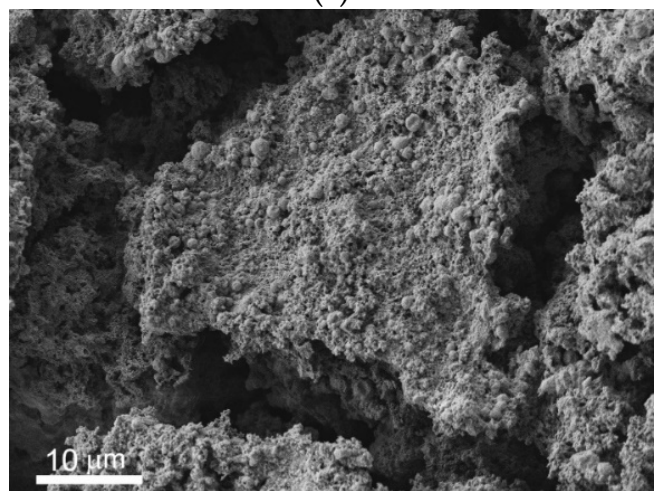

(e)

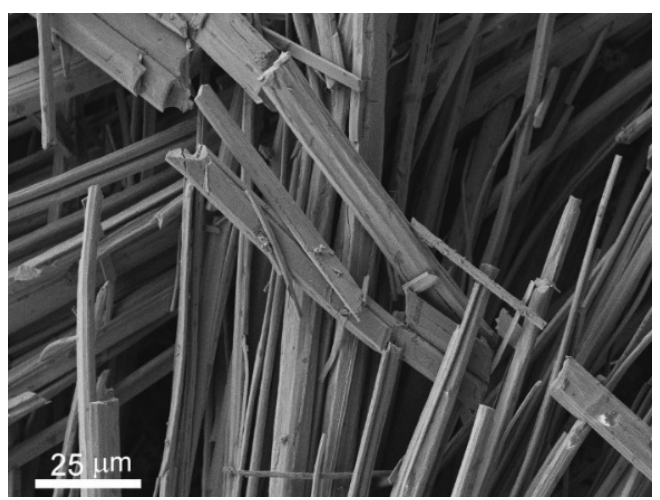

(g)

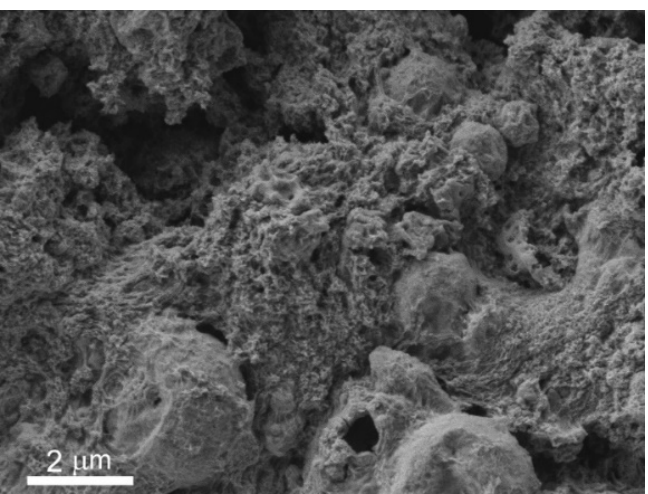

(b)

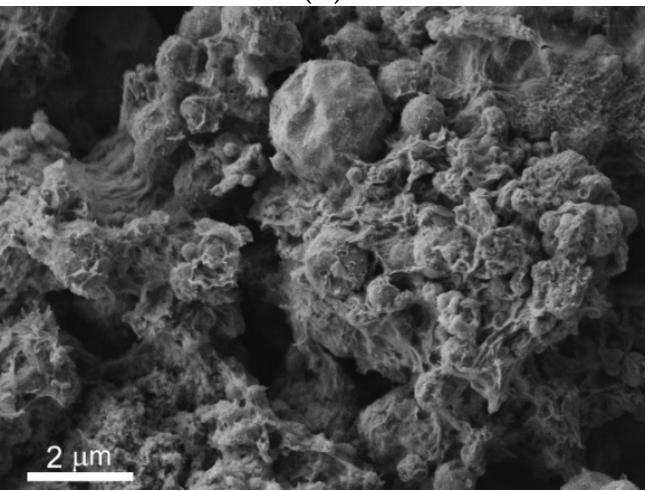

(d)

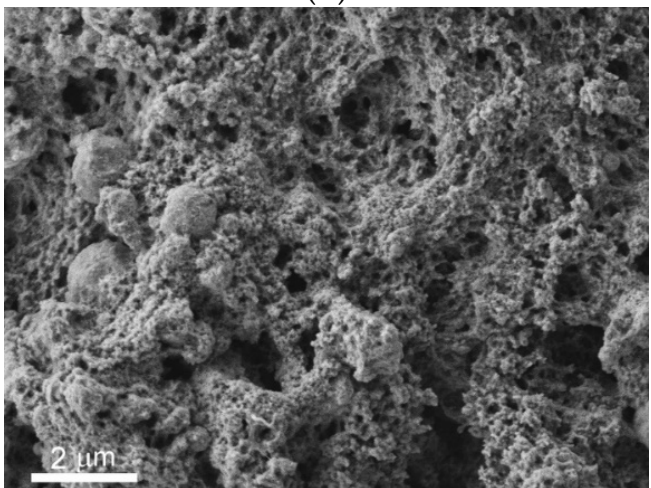

(f)

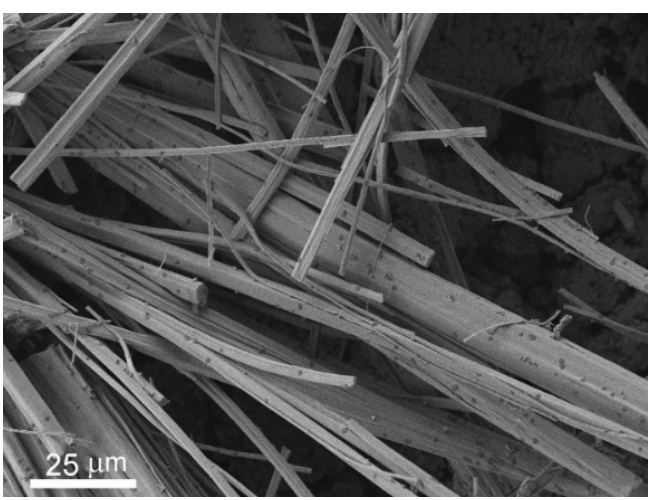

(h)

Figure 1. SEM images illustrating the surface morphology of the superhydrophobic coating on MA8 magnesium alloy: $(\mathbf{a}, \mathbf{b})$ freshly prepared; (c,d) covering film after $48 \mathrm{~h}$ of immersion in bacterial dispersions of K. pneumoniae in PBS; (e,f) covering film after $48 \mathrm{~h}$ of immersion in bacterial dispersions of P. aeruginosa in PBS; (g) microrods formed after $48 \mathrm{~h}$ of immersion in bacterial dispersions of K. pneumoniae in PBS; (h) microrods formed after $48 \mathrm{~h}$ of immersion in bacterial dispersions of P. aeruginosa in PBS. 
The analysis of the SEM images shows the presence of similar features, such as bundles of microrods (Figure 1g,h). However, the newly formed surface layer covering the intrinsic features of the superhydrophobic surface, although it preserves the multimodal surface texture, differs from the original surface, and is different for the samples contacting different bacterial dispersions. A comparison of the SEM images allows us to conclude that the freshly prepared sample demonstrates a dense structure consisting of micro- and nanoelements (Figure 1b), while contact with biological liquids causes structural loosening, either changing to a sponge-like morphology in the case of K. pneumoniae (Figure 1d), or forming a doughy nanostructured layer, in the case of P. aeruginosa (Figure 1f). To understand the mechanism of the formation of these newly developed surface features (the microrods and the covering film), we studied the morphology of the surface of the fabricated coatings after contact with PBS free from bacterial cells. The microrods and covering films formed in the latter case as well. As will be shown below in Section 3.2, the elemental composition of the microrods was the same for both bacterial dispersions and PBS free from bacteria. These data indicate that the impact of bacterial metabolites on microrods formation is too weak (if any) to be detected experimentally, and the main mechanism of microrod formation is related to the chemical interaction of magnesium with components of PBS.

It is well documented in the literature that bare magnesium and its alloys are characterized by a high intrinsic corrosion propensity in the aqueous phase. The anodic and cathodic electrochemical reactions of magnesium in an aqueous solution are presented by the equations

$$
\begin{gathered}
\mathrm{Mg} \rightarrow \mathrm{Mg}^{2+}+2 \mathrm{e}^{-} \rightarrow \text { anodic reaction } \\
2 \mathrm{H}_{2} \mathrm{O}+2 \mathrm{e}^{-} \rightarrow \mathrm{H}_{2} \uparrow+2 \mathrm{OH}^{-} \rightarrow \text { cathodic reaction }
\end{gathered}
$$

The whole electrochemical corrosion process is described by the reaction

$$
\mathrm{Mg}+2 \mathrm{H}_{2} \mathrm{O} \rightarrow \mathrm{Mg}(\mathrm{OH})_{2}+\mathrm{H}_{2} \uparrow
$$

which can be easily detected via the release of hydrogen from and alkalization of the liquid phase. An additional indication of the corrosive process at $\mathrm{pH}>10.5$ is the precipitation of magnesium hydroxide [2]. The precipitated magnesium hydroxide forms a layer on the magnesium's surface; however, this layer does not protect the surface against further magnesium dissolution. The replacement of water with an electrolyte with a complex composition (for example, biological liquids) modifies the corrosion process and diversifies the corrosion products, as well as the kinetics, type, and degree of surface degradation [2,25]. The presence of bacterial cells in the liquid medium contacting the metal surface can either enhance the corrosion process, due to combination with microbiologically induced corrosion, or suppress the corrosion degradation $[22,26]$. The morphological features of the surfaces of the superhydrophobic MA8 after $48 \mathrm{~h}$ of contact with dispersions of P. Aeruginosa and K. pneumoniae show some similarities, such as bundles of microrods, formed as a result of the interaction of magnesium with PBS. To analyze the degradation of the magnesium alloy MA8 with a superhydrophobic coating during immersion in PBS or bacterial dispersions, we studied the variation in the properties of both the substrates and the liquid medium.

Let us first consider the variation in the superhydrophobic sample's wettability over $48 \mathrm{~h}$ of contact with liquid medium. It was found that just after the withdrawal of the sample from the cup with PBS free of bacterial cells, the wettability was notably different from that of the sample before contact with the corrosive medium. The measured contact and roll-off angles became $163.3 \pm 1.0^{\circ}$ and $14.3 \pm 3.9^{\circ}$, respectively. However, washing with a water jet, followed by $30 \mathrm{~min}$ of drying in an oven at $\mathrm{T}=180{ }^{\circ} \mathrm{C}$, led to the nearly complete recovery of the superhydrophobic state, with a contact angle of $170.7 \pm 1.0^{\circ}$ and roll-off angle of $3.5 \pm 2.0^{\circ}$. The analysis of the variation in the wettability of superhydrophobic samples during contact with bacterial dispersions was performed for samples subjected to immersion in bacterial dispersions, followed by immediate washing via water jet, and 
oven-drying at $\mathrm{T}=180^{\circ} \mathrm{C}$ for $30 \mathrm{~min}$. Such immediate heat treatment after the sample's withdrawal from the dispersion was performed to ensure complete bacterial decontamination. The measured wettability of the sample after the described procedure indicated the preservation of a superhydrophobic state for all studied samples in both bacterial strain dispersions. As an example, Figure 2 shows the values of the contact and roll-off angles for one set of experiments using the dispersion of K. pneumoniae and immersion for 1 to $48 \mathrm{~h}$. Two values are given for each immersion time, one corresponding to the sample before immersion (blue symbols) and the other showing the sample after a certain time of immersion (red symbols).

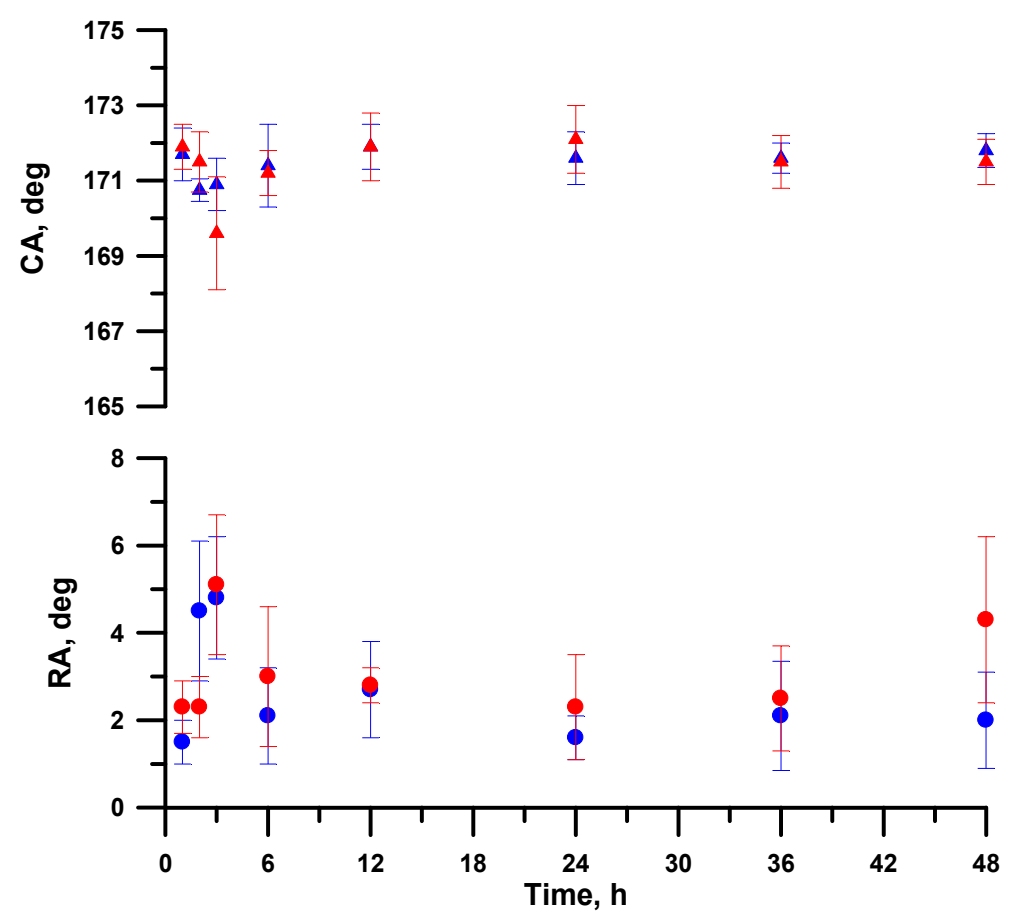

Figure 2. The contact (triangles) and roll-off (circles) angles for the superhydrophobic samples before (blue symbols) and after (red symbols) different durations of immersion in the dispersion of K. pneumoniae. A separate freshly prepared sample was used for each immersion duration; that is why the initial values (blue symbols) show some variation.

As can be concluded from an analysis of the presented data, the degradation of the superhydrophobic state for all samples, if indeed there was any, was weak. At the same time, the significant differences in the morphology suggest the modification of the surface layer's composition during contact with the bacterial dispersions. That is why the second step in our study was related to the analysis of the surface's composition.

\subsection{Variation in Surface Composition of a Superhydrophobic Coating}

The X-ray diffraction patterns (Figure 3a) of the superhydrophobic samples-one of which (1) had no contact with the corrosive medium, and the other two (2 and 3) of which were immersed for $48 \mathrm{~h}$ in bacterial dispersions of K. pneumoniae and P. Aeruginosa, respectively-are dominated by reflections from $\mathrm{MgO}$. This oxide is formed during the interaction of laser irradiation with the magnesium alloy's surface in the presence of atmospheric oxygen. In samples 2 and 3, the amorphous material was abundant. Unambiguous phase identification for the other surface phases is difficult due to broad variations in cation composition, the degree of crystallinity, and the hydration of many complex phosphates. Orthorhombic hydrated sodium polyphosphate $\mathrm{Na}_{6} \mathrm{P}_{6} \mathrm{O}_{18} \cdot 6 \mathrm{H}_{2} \mathrm{O}$ was observed in sample 2 , and in a smaller amount in sample 3 . Weak reflections from other crystalline phases were 
also found, but their assignment is not certain. Possible candidates include varieties of $\mathrm{Mg}$, $\mathrm{Na}$, and $\mathrm{K}$ hydrophosphates.
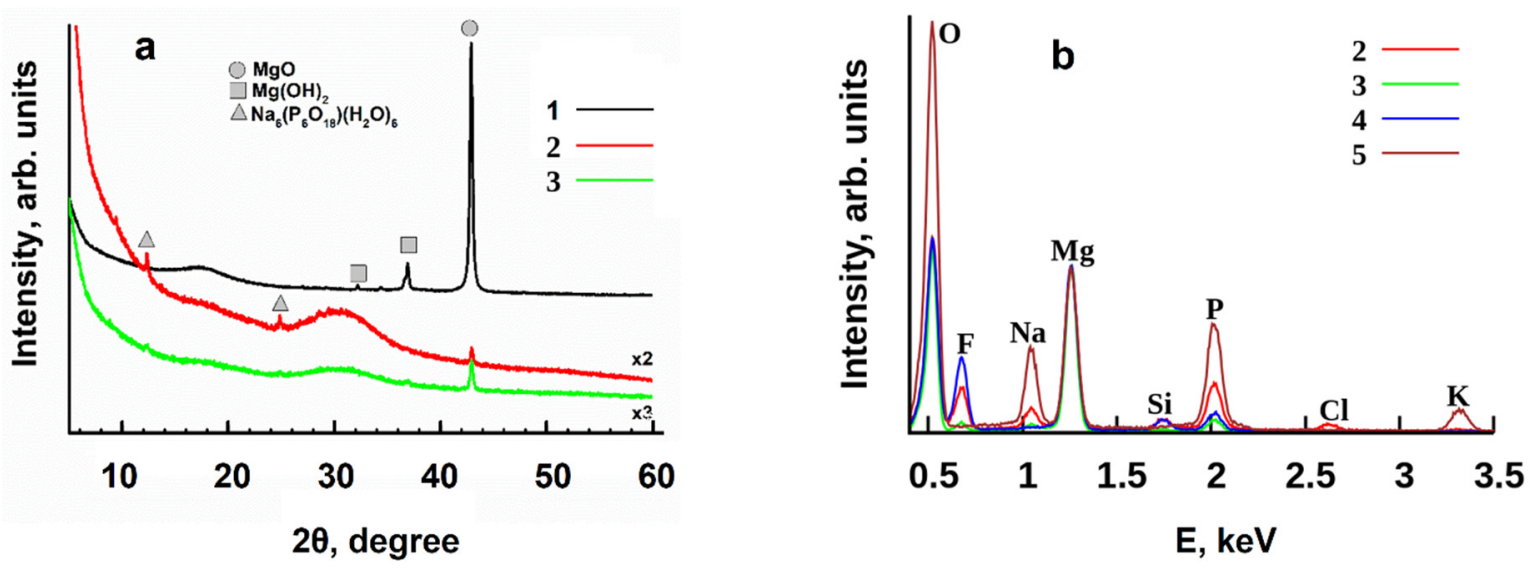

Figure 3. X-ray diffraction patterns (a) and EDS spectra (b) for the superhydrophobic samples before contact with biological liquids (1) and after $48 \mathrm{~h}$ of immersion in dispersions of K. pneumoniae (2), P. Aeruginosa (3), or PBS without bacteria (4). The EDS spectrum (5) was measured for bundles of microrods (such as those in Figure 1g,h), and was characteristic of microrods formed in both PBS dispersions studied, as well in PBS without bacteria.

The EDS spectra (Figure 3b) were measured separately for the rods and the areas free of microrods on the surfaces of samples 2 and 3 in the bacterial dispersions. It was found that the rods' composition was not sensitive to the type of bacterial cells, and was the same for the two bacterial dispersions in PBS and for PBS free of cells. The main components of the rods were $\mathrm{Mg}, \mathrm{Na}$, and $\mathrm{K}$ hydrophosphates. The covering films that formed on the superhydrophobic surfaces in two studied bacterial dispersions differ from each other by the amount of phosphorous, potassium, and sodium. Additionally, notably lower peaks corresponding to the components of the very top layer of the superhydrophobic structure, such as silicon and fluorine, were registered by EDS. Jointly with the data of $X$-ray diffraction, indicating the presence of the amorphous material, a decrease in the height of the F and Si peaks along with the preservation of a superhydrophobic state in the sample indicates the presence of hydrocarbon deposits. Such deposits formed on the surface as a constituent of biofilm, resulting from the interaction of bacterial cells with the superhydrophobic surface. The thicker the newly formed biofilm, the weaker the EDS signal from the superhydrophobic coating. To examine this hypothesis, we measured the FT-IR reflectance spectra of the surface in the $3500-2500 \mathrm{~cm}^{-1}$ range of wave numbers, corresponding to stretching $\mathrm{C}-\mathrm{H}$ vibrations (Figure 4). Indeed, greater $\mathrm{C}-\mathrm{H}$ absorption, leading to lower reflectance of IR irradiation from the surface, was detected for the sample in contact with P. Aeruginosa cells in comparison to the sample immersed in K. pneumoniae dispersion. Such behavior, indicating a thicker biofilm in the former case, correlates well with the lower F and Si peaks in the EDS spectra.

The formation of such a biofilm on top of a superhydrophobic surface should affect the bactericidal action of magnesium, with respect to the bacterial cell, the alkalinity of the liquid phase, and the corrosion resistance of the superhydrophobic coating when in contact with bacterial dispersions. 


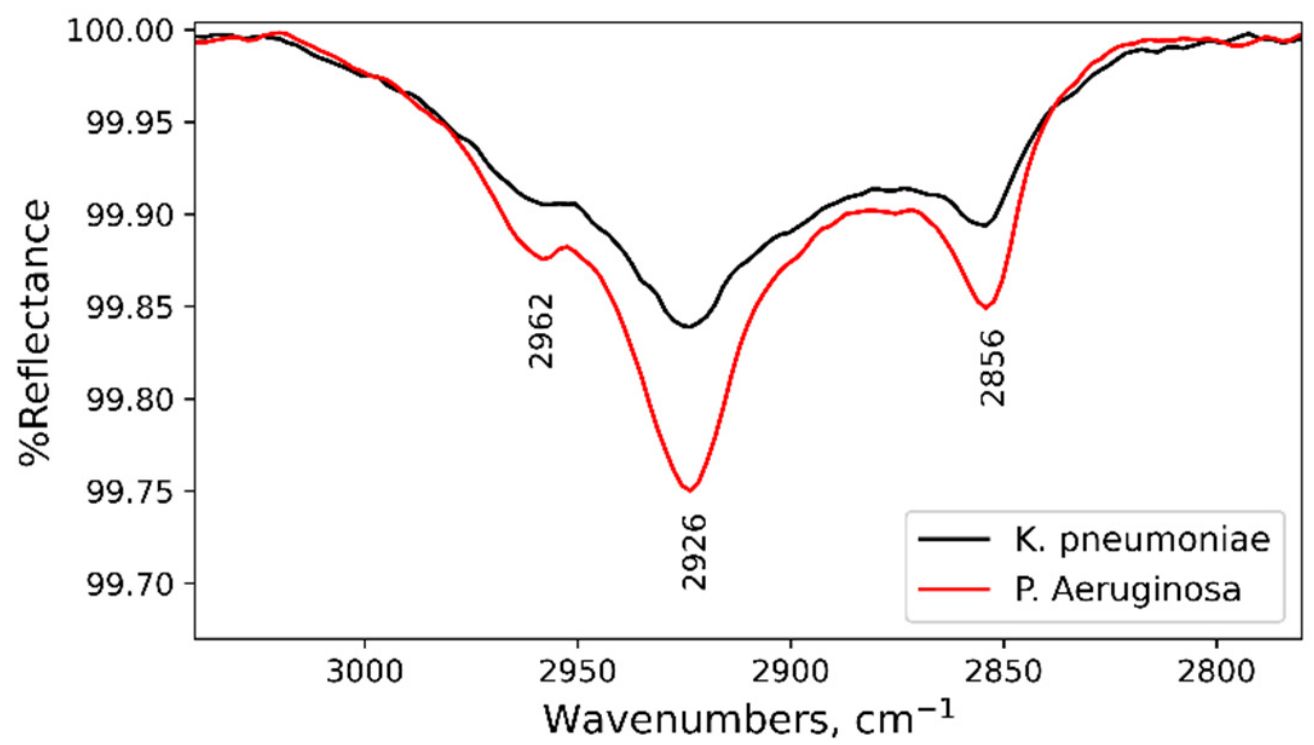

Figure 4. FT-IR reflectance spectra for the surfaces of superhydrophobic samples after $48 \mathrm{~h}$ of immersion in dispersions of K. pneumoniae and P. Aeruginosa. The reflectance bands at $2856 \mathrm{~cm}^{-1}$ and $2926 \mathrm{~cm}^{-1}$ correspond to symmetric and asymmetric $\mathrm{C}-\mathrm{H}$ stretching vibrations in $\mathrm{CH}_{2}$ groups, while band $2962 \mathrm{~cm}^{-1}$ arises due to asymmetric $\mathrm{C}-\mathrm{H}$ vibration in the $\mathrm{CH}_{3}$ group [27] of bacterial cell membranes.

\subsection{Antibacterial Activity of Superhydrophobic Coatings in Bacterial Dispersions}

The bacterial activity of the superhydrophobic samples of MA8 alloy immersed in bacterial dispersion, with respect to planktonic forms of K. pneumoniae or P. Aeruginosa, was estimated by monitoring the evolution of the bacterial titer in the dispersion when the sample was immersed (Figure 5). For comparison, the evolution of the bacterial titer in the control dispersions not in contact with a superhydrophobic surface is presented. The analysis of the data obtained for both the control bacterial dispersions indicates that that the number of living cells weakly increased with time over the $48 \mathrm{~h}$ of monitoring. Thus, PBS can be considered as a friendly medium for bacterial cell growth, at least for the studied time. As for the titer of dispersions that was in contact with the superhydrophobic magnesium samples, it was found that the titer of K. pneumoniae started to notably decrease only after $12 \mathrm{~h}$ of contact. Such reduction in the antibacterial activity of the superhydrophobic plate compared to the bare metal is related to the high protective action of a superhydrophobic surface, which inhibits the transition of ions, charges, and water molecules through the superhydrophobic textured layer, suppresses the adhesion of bacterial cells onto the surface, and significantly decreases the rate of metal dissolution. However, after $48 \mathrm{~h}$, the dispersion can be considered free from bacterial contamination. Since the wettability studies described above indicated the preservation of a superhydrophobic state in the sample after $48 \mathrm{~h}$ of contact with the dispersion, and only an insignificant decrease in contact angles and an increase in roll-off angles were shown, the observed bactericidal action is seemingly related to the appearance of a few wetting defects. 


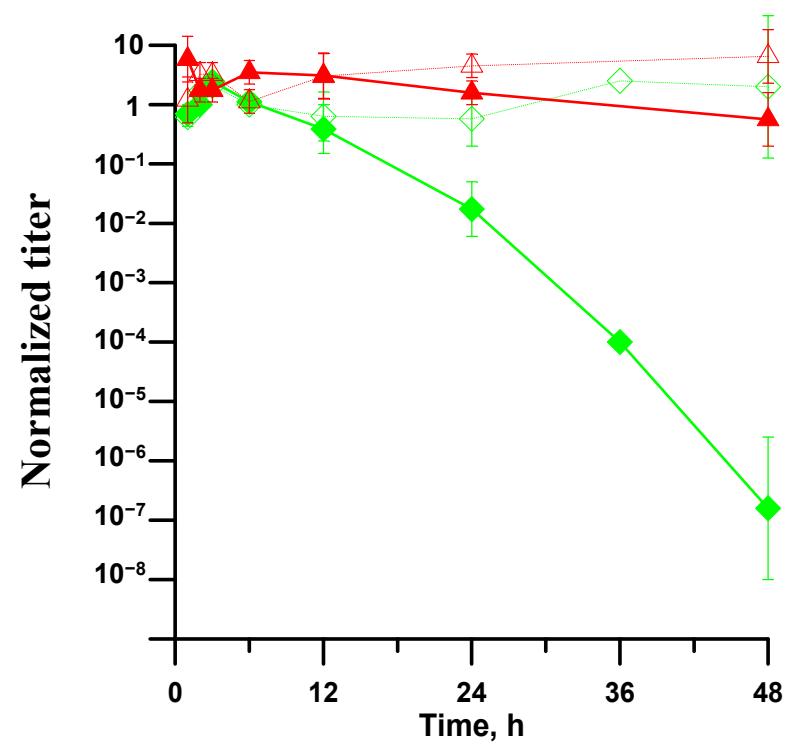

Figure 5. Time evolution of bacterial titer of K. pneumoniae (green diamonds) and P. Aeruginosa (red triangles) in the bacterial dispersion in contact with the immersed MA8 alloy sample with a superhydrophobic coating (full symbols). Empty symbols show the corresponding variation in the bacterial titer in the control dispersions without immersed samples. The normalized titer was calculated as a ratio of the titer in an assay taken at a given time to the initial titer in the dispersion.

In contrast, the biofilm on top of the superhydrophobic surface that was immersed in a bacterial dispersion of $P$. Aeruginosa additionally inhibited the bactericidal action of the metal. Even after $48 \mathrm{~h}$ of contact with the superhydrophobic sample, the titer of P. Aeruginosa cells in the dispersion remained as high as $50 \%$ of the initial titer.

An analysis of the literature shows that there is still no consensus on the nature of the anti-bacterial activity of magnesium alloys. The main mechanisms of toxic action discussed in the literature are [2-5]: (1) the high reactivity of $\mathrm{Mg}$ in contact with aqueous media, leading to the formation of superoxide ions $\left(\mathrm{O}^{2-}\right)$; (2) an excess of magnesium ions in the aqueous medium surrounding the cells, leading to osmotic effects that destroy cell's membranes; (3) an increase in pH during the corrosion of magnesium in biological media. Additionally, two mechanisms specific to any superhydrophobic material should be taken into account [28-32]: (4) the low adhesion of bacterial cells to the superhydrophobic surface; and (5) the mechanical damage of cell membranes in the cells deposited onto the surface. The analysis of mechanism (1), related to oxidation stress, is beyond the scope and technical capabilities of this study. The antibacterial mechanisms (4) and (5), related to the superhydrophobic state, are significant, but not determinative for the planktonic forms of bacteria. The evolution of the $\mathrm{pH}$ in the PBS and bacterial dispersions, as well as the behavior of the $\mathrm{Mg}^{2+}$ ions in the dispersion medium, will be discussed in the next section.

\subsection{Variation of $\mathrm{pH}$ in Dispersion Medium during Its Contact with a Superhydrophobic Sample}

To monitor the variation in $\mathrm{pH}$, which can be considered an indicator of magnesium alloy dissolution in both PBS free from bacterial cells and PBS with bacterial dispersions, the magnesium alloy samples were immersed in the liquid, with a ratio of apparent sample surface to liquid volume of $0.8 \mathrm{~cm}^{2} / \mathrm{mL}$, as described above. Data on the variation in $\mathrm{pH}$ are presented in Figure 6. 


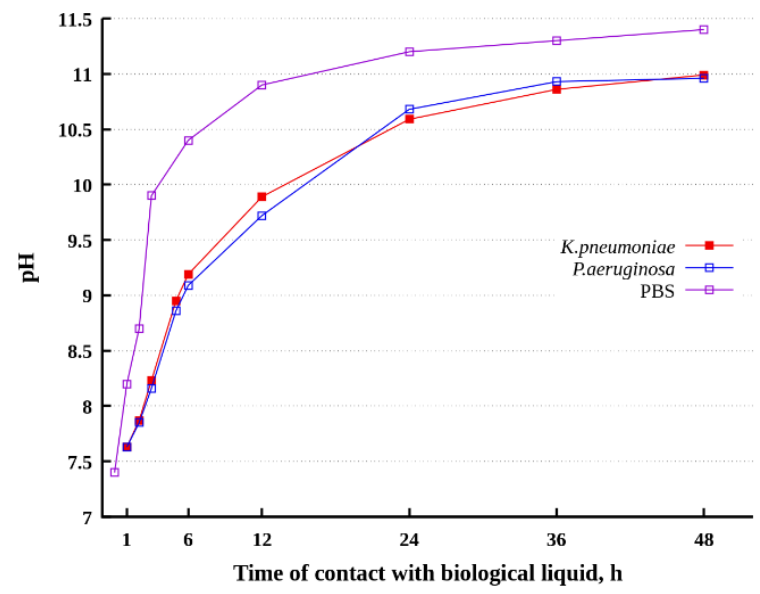

Figure 6. Variation in $\mathrm{pH}$ with duration of contact between the MA8 alloy sample with the superhydrophobic coating and PBS with or without bacterial cells.

After immersing the superhydrophobic sample for $48 \mathrm{~h}$ in PBS free from bacterial cells, a rapid increase in the $\mathrm{pH}$ of the liquid from 7.4 to 11.4 was detected. Such alkalization takes place due to the cathodic reaction (2).

Here, it is worth noting that the superhydrophobic state of magnesium surface provides notable anticorrosion protection in neutral chloride-containing media. However, a significant $\mathrm{pH}$ increase causes the hydrolysis of $\mathrm{Si}-\mathrm{O}$ and $\mathrm{Si}-\mathrm{C}$ bonds in the molecules of fluorooxysilane, used here as a hydrophobic agent [21]. Such hydrolysis results in the hydrophobic molecules' desorption from the surface, and the formation of wetting defects, which act as channels for ion and charge transfers through the surface layer of the sample, and thus cause some degradation of the magnesium alloy.

In the presence of chloride ions in the alkaline solution, the substitution reaction transforms magnesium hydroxide into soluble chloride, which allows for an increase in $\mathrm{pH}$ to values higher than $\mathrm{pH}=10.5$, corresponding to magnesium hydroxide precipitation. In turn, the interaction of the magnesium ions with $\mathrm{KH}_{2} \mathrm{PO}_{4}$ monopotassium phosphate or $\mathrm{Na}_{2} \mathrm{HPO}_{4}$ disodium phosphate will cause the formation of weakly soluble mixed magnesium, potassium and sodium phosphates, which deposit onto the surface as a covering film (Figure 3b) or as rod-like crystals (Figure 1).

The data presented in Figure 6 for the evolution of $\mathrm{pH}$ in bacterial dispersions indicate the partial suppression of the alkalization of the dispersion medium in the presence of bacterial cells. This observed phenomena can be related to the additional protective action of the covering surface film, which grew on the superhydrophobic surfaces in the bacterial dispersions in PBS. At the same time, even in the presence of bacterial cells, the $\mathrm{pH}$ reached values as high as $\mathrm{pH}=11.0$.

The capturing of magnesium by weakly soluble compounds is additionally substantiated by the low magnesium concentration in the liquid medium (Figure 7). Bearing in mind that the concentrations of $\mathrm{Mg}^{2+}$ obtained here are notably lower than those discussed in the literature as toxic, and are of the same order as the typical concentrations in cellular liquids $[2,33,34]$, we can exclude from consideration the mechanism of bacteria-killing associated with the osmotic effects of super-high concentrations of magnesium in the systems under consideration. 


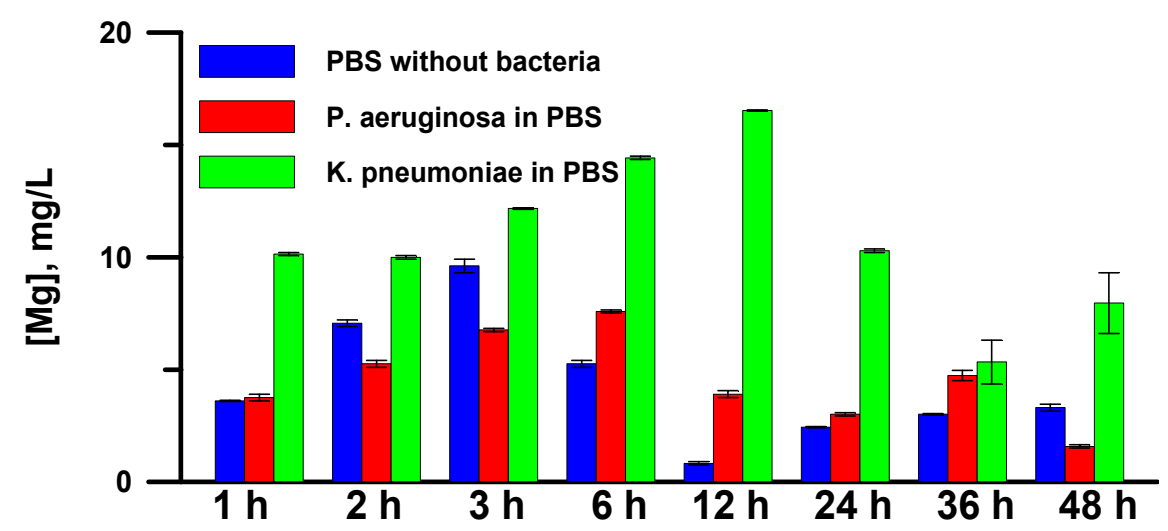

Figure 7. Variation in magnesium concentration in liquid phase with the duration of contact between the MA8 alloy sample with a superhydrophobic coating and PBS with or without bacterial cells.

The nonmonotonic increase in $\mathrm{Mg}^{2+}$ concentration over time for all three considered liquid media is seemingly determined by the kinetics of the formation of the covering films and the rods on the surfaces of the superhydrophobic samples. Since the superhydrophobic surface is characterized by an increased energetic barrier for the heterogeneous nucleation of the surface phases [35], we observed an increase in the concentration of magnesium ions that reached the saturation levels necessary to start the mass formation of a new phase (Figure 7).

To present more information on the degradation behavior of superhydrophobic surfaces in PBS and bacterial dispersions in PBS, the electrochemical parameters of the superhydrophobic sample will be given in the next section.

\subsection{Anticorrosion Behavior of Superhydrophobic Coatings}

The superhydrophobic coating on the surface of MA8, obtained by laser treatment followed by the chemisorption of fluorooxysilane, functions as a good protective anticorrosive coating that inhibits the evolution of hydrogen and the formation of crystalline hydrates on the surface. The change in the state of such samples and their possible corrosive degradation were quantitatively characterized in Section 3; here, we will use voltammetry and impedance spectroscopy for deeper analysis. The corrosion currents and the spectra of the impedance modulus were measured before and after the immersion of the samples in bacterial dispersion for $1,2,3,6,12,24,36$, and $48 \mathrm{~h}$. It is worth noting that high-quality superhydrophobic surfaces are characterized by extremely low corrosion currents and high impedance values at low frequencies. That is why even minor wetting defects on the surface may cause a one order of magnitude variation in the corrosion current and the modulus of impedance. To avoid uncertainty in the initial characteristics of the samples used for this study, we have compared the corresponding characteristics of each sample before and after contact with the bacterial dispersions. Two different samples were used for each duration of immersion and for each type of dispersion. Figure 8 shows the obtained values of corrosion current density and impedance modulus before and after contact with the bacterial dispersion for individual superhydrophobic samples. 

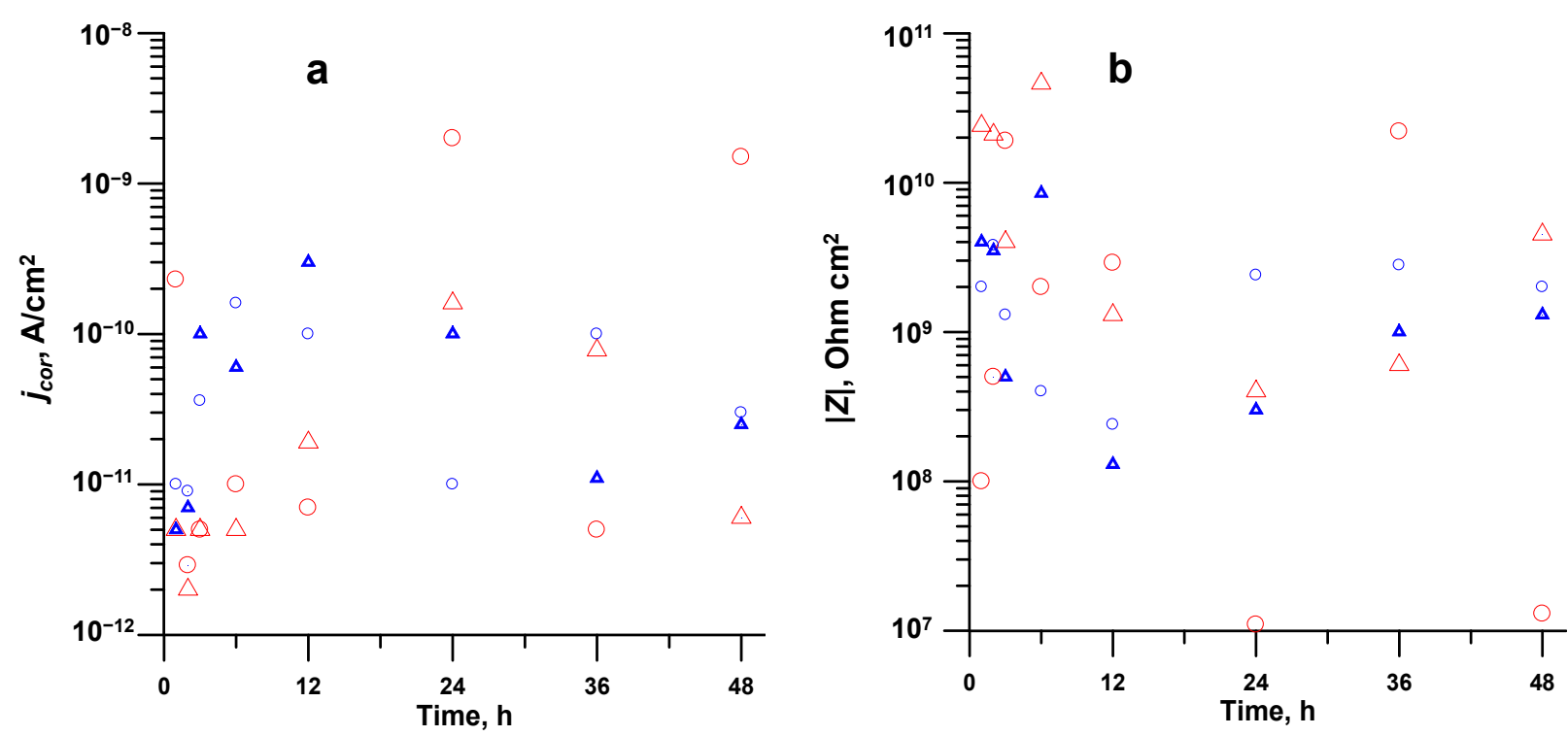

Figure 8. Change in corrosion current density (a) and low-frequency $(f=0.05 \mathrm{~Hz})$ impedance modulus (b) with different durations of immersion of superhydrophobic magnesium samples in P. aeruginosa dispersion in PBS. Blue and red symbols denote the values measured before and after immersion, respectively; for each time of immersion, the same symbols (triangles or circles) are related to the same sample.

The presented data indicate weak changes in the electrochemical parameters of coatings even with prolonged (for $48 \mathrm{~h}$ ) contact of the magnesium alloy with a corrosive biological environment. In this case, for a majority of samples, no degradation in the anticorrosive properties of the coating was detected; however, an increase in the corrosion resistance was indicated by a decrease in corrosion currents and an increase in impedance moduli. The possible mechanisms of the inhibition of biocorrosion on different metal surfaces, including superhydrophobic surfaces, as discussed in the literature earlier [22,36,37], are as follows: (1) the suppression of the growth of corrosive bacteria by antimicrobial drugs; (2) the release of a peptide corrosion inhibitor; (3) the formation of a protective layer in the case of the physiological activity of bacteria or the strong adhesion of bacterial cells to the interface; (4) the formation of a protective layer by corrosion products; finally, (5) the removal of corrosive agents due to the physiological activity of bacteria. Our data allow us to associate the corrosion inhibition in the systems considered here with two factors: Firstly, the formation of a protective layer due to the physiological activity of bacteria. The formation of such a layer, referred to here as a biofilm and containing hydrocarbon components and mixed phosphates of magnesium, potassium, and sodium, is indicated by the data of IR spectroscopy (Figure 4) and EDS (Figure 3b). The second factor is related to the formation of layers of corrosion products-magnesium phosphates. Besides this, the XRD data indicate the precipitation of sodium polyphosphate from the liquid phase onto the superhydrophobic surface. Phosphate coatings, such as the magnesium phosphate or sodium polyphosphates formed by different means, have been repeatedly employed in earlier studies, and have been shown to be able to improve the anticorrosion performance of Mg-based biomaterials [38-42].

\section{Conclusions}

The bare magnesium alloy MA8 is characterized by low corrosion resistance in different media, leading to the rapid degradation of magnesium-based materials. It was shown in recent studies that the fabrication of superhydrophobic coatings on the surfaces of such materials significantly enhances the stability of the materials against different types of degradation, including the corrosion phenomena. In this study, we have analyzed the behavior and the impact of the interaction of superhydrophobic MA8 samples with different 
corrosive media. Experiments were performed in phosphate-buffered saline solutions and dispersions of bacterial cells P. Aeruginosa and K. pneumoniae in PBS.

The superhydrophobic samples used were characterized by extremely high initial corrosion resistance values in chloride-containing solutions. The immersion of such samples into bacterial dispersions resulted in notable changes in the morphology of the samples, due to the deposition of corrosion products related to the formation of a covering film, and bundles of rods of magnesium phosphates and mixed magnesium, potassium, and sodium phosphates. Corrosion reactions caused a significant increase in $\mathrm{pH}$ and, consequently, bacterial cell killing. It was found that the bactericidal activity of superhydrophobic coatings is dependent on the bacterial strain. It was shown that the mechanism of such dependence is related to the composition and thickness of the film, composed of corrosion products, on the superhydrophobic surface throughout its interaction with the components of the dispersion.

The analysis of the elemental composition of the film covering the superhydrophobic surface indicated negligible amounts of potassium and sodium in the films formed in PBS. In contrast, significant amounts of sodium were found in the surface films grown in bacterial dispersions. Besides this, the films grown on the surface in contact with the dispersion of $P$. Aeruginosa were characterized by greater amounts of hydrocarbon components, which were seemingly formed as a product of cell metabolism in the alkaline conditions, compared to the films on the superhydrophobic surfaces in contact with the dispersion of K. pneumoniae. The formation of biofilms and sodium polyphosphate films provided enhanced barrier properties for magnesium dissolution and hence for dispersion medium alkalization, leading to the inhibition of magnesium substrate degradation. The electrochemical data obtained for superhydrophobic samples in continuous contact with the corrosive bacterial dispersions for $48 \mathrm{~h}$ indicate a high level of protective anticorrosion properties in the fabricated superhydrophobic coatings, and their ability to partially inhibit the medium alkalization. The corrosion currents for the samples immersed in bacterial dispersions in PBS followed by oven-drying had values of the order $10^{-10}-10^{-11} \mathrm{~A} / \mathrm{cm}^{2}$. These currents are five to six orders of magnitude lower than the currents characteristic of bare alloy, which did not come into contact with the corrosive medium.

Author Contributions: Conceptualization, A.M.E., K.A.E. and L.B.B.; methodology, V.V.K., A.M.E. and A.A.S.; formal analysis, A.V.A.; investigation, V.V.K., I.S.P., K.A.E., A.G.D., E.V.C. and A.A.S.; writing-original draft preparation, L.B.B.; writing—review and editing, A.M.E. and L.B.B.; visualization, A.M.E., K.A.E. and A.G.D.; supervision, L.B.B.; project administration, A.M.E.; funding acquisition, A.M.E. and K.A.E. All authors have read and agreed to the published version of the manuscript.

Funding: This research was funded by the Russian Foundation for Basic Research (grant \#18-2905008) and by the Ministry of Science and Higher Education of the Russian Federation. The selection of regimes for sample fabrication was conducted under the Russian Federation President's grant for young research groups MK-2124.2021.1.3.

Institutional Review Board Statement: Not applicable.

Informed Consent Statement: Not applicable.

Data Availability Statement: Data are contained within the article.

Acknowledgments: The XRD measurements were performed using the equipment of CKP FMI IPCE RAS; the SEM and EDX studies were performed using the equipment of the IGIC RAS Joint Research Centre for Physical Methods of Research.

Conflicts of Interest: The authors declare no conflict of interest. The funders had no role in the design of the study; in the collection, analyses, or interpretation of data; in the writing of the manuscript, or in the decision to publish the results. 


\section{References}

1. Maier, P.; Hort, N. Magnesium alloys for biomedical applications. Metals 2020, 10, 1328. [CrossRef]

2. Luque-Agudo, V.; Fernández-Calderón, M.C.; Pacha-Olivenza, M.A.; Pérez-Giraldo, C.; Gallardo-Moreno, A.M.; González-Martín, M.L. The role of magnesium in biomaterials related infections. Colloids Surf. B Biointerfaces 2020, 191, 110996. [CrossRef]

3. Rahim, M.I.; Eifler, R.; Rais, B.; Mueller, P.P. Alkalization is responsible for antibacterial effects of corroding magnesium. J. Biomed. Mater. Res. Part A 2015, 103, 3526-3532. [CrossRef]

4. Feng, H.; Wang, G.; Jin, W.; Zhang, X.; Huang, Y.; Gao, A.; Wu, H.; Wu, G.; Chu, P.K. Systematic study of inherent antibacterial properties of magnesium-based biomaterials. ACS Appl. Mater. Interfaces 2016, 8, 9662-9673. [CrossRef] [PubMed]

5. Son, J.; Oh, J.K.; Cho, D.H.; Akbulut, M.; Teizer, W. Bacterial inactivation characteristics of magnesium-calcium-zinc alloys for bone implants. MRS Commun. 2020, 10, 609-612. [CrossRef]

6. Rosalbino, F.; De Negri, S.; Scavino, G.; Saccone, A. Microstructure and in vitro degradation performance of Mg-Zn-Mn alloys for biomedical application. J. Biomed. Mater. Res. Part A 2013, 101, 704-711. [CrossRef] [PubMed]

7. Gao, C.; Li, S.; Liu, L.; Bin, S.; Yang, Y.; Peng, S.; Shuai, C. Dual alloying improves the corrosion resistance of biodegradable Mg alloys prepared by selective laser melting. J. Magnes. Alloys 2021, 9, 305-316. [CrossRef]

8. Mueller, W.D.; Nascimento, M.L.; De Mele, M.F.L. Critical discussion of the results from different corrosion studies of Mg and Mg alloys for biomaterial applications. Acta Biomater. 2010, 6, 1749-1755. [CrossRef]

9. Leones, A.; Lieblich, M.; Benavente, R.; Gonzalez, J.L.; Peponi, L. Potential applications of magnesium-based polymeric nanocomposites obtained by electrospinning technique. Nanomaterials 2020, 10, 1524. [CrossRef] [PubMed]

10. Li, L.Y.; Cui, L.Y.; Zeng, R.C.; Li, S.Q.; Chen, X.B.; Zheng, Y.F.; Kannan, M.B. Advances in functionalized polymer coatings on biodegradable magnesium alloys-A review. Acta Biomater. 2018, 79, 23-36. [CrossRef]

11. Zhang, D.; Liu, Y.; Liu, Z.; Wang, Q. Advances in antibacterial functionalized coatings on Mg and its alloys for medical use-A review. Coatings 2020, 10, 828. [CrossRef]

12. Ren, L.; Lin, X.; Tan, L.; Yang, K. Effect of surface coating on antibacterial behavior of magnesium based metals. Mater. Lett. 2011, 65, 3509-3511. [CrossRef]

13. Gray-Munro, J.; Campbell, J. Mimicking the hierarchical surface topography and superhydrophobicity of the lotus leaf on magnesium alloy AZ31. Mater. Lett. 2017, 189, 271-274. [CrossRef]

14. Ishizaki, T.; Kumagai, S.; Tsunakawa, M.; Furukawa, T.; Nakamura, K. Ultrafast fabrication of superhydrophobic surfaces on engineering light metals by single-step immersion process. Mater. Lett. 2017, 193, 42-45. [CrossRef]

15. Boinovich, L.B.; Emelyanenko, A.M.; Pashinin, A.S.; Gnedenkov, S.V.; Egorkin, V.S.; Sinebryukhov, S.L. Mg alloy treatment for superhydrophobic anticorrosion coatings formation. Surf. Innov. 2013, 1, 162-172. [CrossRef]

16. Yeganeh, M.; Mohammadi, N. Superhydrophobic surface of Mg alloys: A review. J. Magnes. Alloys 2018, 6, 59-70. [CrossRef]

17. Emelyanenko, K.A.; Domantovsky, A.G.; Chulkova, E.V.; Emelyanenko, A.M.; Boinovich, L.B. Thermally induced gradient of properties on a superhydrophobic magnesium alloy surface. Metals 2021, 11, 41. [CrossRef]

18. Chobaomsup, M.; Metzner, M.; Boonyongmaneerat, Y. Superhydrophobic surface modification for corrosion protection of metals and alloys. J. Coat. Technol. Res. 2020, 17, 583-595. [CrossRef]

19. Yao, W.; Wu, L.; Huang, G.; Jiang, B.; Atrens, A.; Pan, F. Superhydrophobic coatings for corrosion protection of magnesium alloys. J. Mater. Sci. Technol. 2020, 52, 100-118. [CrossRef]

20. Zhao, X.; Wei, J.; Li, B.; Li, S.; Tian, N.; Jing, L.; Zhang, J. A self-healing superamphiphobic coating for efficient corrosion protection of magnesium alloy. J. Colloid Interface Sci. 2020, 575, 140-149. [CrossRef] [PubMed]

21. Boinovich, L.B.; Emelyanenko, A.M. The behaviour of fluoro- and hydrocarbon surfactants used for fabrication of superhydrophobic coatings at solid/water interface. Colloids Surf. A Physicochem. Eng. Asp. 2015, 481, 167-175. [CrossRef]

22. Emelyanenko, A.M.; Pytskii, I.S.; Kaminsky, V.V.; Chulkova, E.V.; Domantovsky, A.G.; Emelyanenko, K.A.; Sobolev, V.D.; Aleshkin, A.V.; Boinovich, L.B. Superhydrophobic copper in biological liquids: Antibacterial activity and microbiologically induced or inhibited corrosion. Colloids Surf. B Biointerfaces 2020, 185, 110622. [CrossRef] [PubMed]

23. Chang, T.R.; Butina, K.; Herting, G.; Rajarao, G.K.; Richter-Dahlfors, A.; Blomberg, E.; Wallinder, I.O.; Leygraf, C. The interplay between atmospheric corrosion and antimicrobial efficiency of $\mathrm{Cu}$ and $\mathrm{Cu}$ ZZn5Al1Sn during simulated high-touch conditions. Corros. Sci. 2021, 185, 109433. [CrossRef]

24. Boinovich, L.B.; Emelyanenko, A.M. Analysis of wetting as an efficient method for studying the characteristics of coatings and surfaces and the processes that occur on them: A review. Inorg. Mater. 2011, 47, 1667-1675. [CrossRef]

25. Heimann, R.B. Magnesium alloys for biomedical application: Advanced corrosion control through surface coating. Surf. Coat. Technol. 2021, 405, 126521. [CrossRef]

26. Little, B.; Wagner, P.; Mansfeld, F. Microbiologically influenced corrosion of metals and alloys. Int. Mater. Rev. 1991, 36, 253-272. [CrossRef]

27. Duncan, A.B.F.; Gordy, W.; Jones, R.N.; Matsen, F.A.; Sandorfy, C.; West, W. Technique of Organic Chemistry. Volume IX: Chemical applications of spectroscopy; West, W., Ed.; Interscience Publishers: New York, NY, USA, 1956.

28. Lima, A.C.; Mano, J.F. Micro/nano-structured superhydrophobic surfaces in the biomedical field: Part I: Basic concepts and biomimetic approaches. Nanomedicine 2015, 10, 103-119. [CrossRef]

29. Falde, E.J.; Yohe, S.T.; Colson, Y.L.; Grinstaff, M.W. Superhydrophobic materials for biomedical applications. Biomaterials 2016, 104, 87-103. [CrossRef] 
30. Boinovich, L.B.; Modin, E.B.; Aleshkin, A.V.; Emelyanenko, K.A.; Zulkarneev, E.R.; Kiseleva, I.A.; Vasiliev, A.L.; Emelyanenko, A.M. Antibacterial effect of textured surfaces induced by extreme wettability and bacteriophage seeding. ACS Appl. Nanomater. 2018, 1, 1348-1359. [CrossRef]

31. Tripathy, A.; Sen, P.; Su, B.; Briscoe, W.H. Natural and bioinspired nanostructured bactericidal surfaces. Adv. Colloid Interface Sci. 2017, 248, 85-104. [CrossRef]

32. Muller, D.W.; Losslein, S.; Terriac, E.; Moeller, R.; Kautenburger, R.; Mucklich, F. Increasing antibacterial efficiency of Cu surfaces by targeted surface functionalization via ultrashort pulsed direct laser interference patterning. Adv. Mater. Interfaces 2021, 8, 2001656. [CrossRef]

33. Lin, Z.; Sun, X.; Yang, H. The role of antibacterial metallic elements in simultaneously improving the corrosion resistance and antibacterial activity of magnesium alloys. Mater. Des. 2021, 198, 109350. [CrossRef]

34. Jahnen-Dechent, W.; Ketteler, M. Magnesium basics. Clin. Kidney J. 2021, 5 (Suppl. S1), i3-i14. [CrossRef]

35. Emelyanenko, A.M.; Emelyanenko, K.A.; Boinovich, L.B. Deep undercooling of aqueous droplets on a superhydrophobic surface: The specific role of cation hydration. J. Phys. Chem. Lett. 2020, 11, 3058-3062. [CrossRef]

36. Little, B.; Ray, R. A perspective on corrosion inhibition by biofilms. Corrosion 2002, 58, 424-428. [CrossRef]

37. Zarasvand, K.A.; Rai, V.R. Microorganisms: Induction and inhibition of corrosion in metals. Int. Biodeterior. Biodegrad. 2014, 87, 66-74. [CrossRef]

38. Ishizaki, T.; Shigematsu, I.; Saito, N. Surface \& coatings technology anticorrosive magnesium phosphate coating on AZ31 magnesium alloy. Surf. Coat. Technol. 2009, 203, 2288-2291. [CrossRef]

39. Van Phuong, N.; Gupta, M.; Moon, S. Enhanced corrosion performance of magnesium phosphate conversion coating on AZ31 magnesium alloy. Trans. Nonferrous Met. Soc. China 2017, 27, 1087-1095. [CrossRef]

40. El-Taib Heakal, F.; Shehata, O.S.; Tantawy, N.S. Degradation behaviour of AZ80E magnesium alloy exposed to phosphate buffer saline medium. Corros. Sci. 2014, 86, 285-294. [CrossRef]

41. Cabeza, S.; Zubiaur, P.P.; Garcés, G.; Andrade, C.; Adeva, P. Corrosion behaviour of Mg98.5Nd1Zn0.5 (at. \%) alloy in phosphate buffered saline solution. Metals 2020, 10, 148. [CrossRef]

42. Huang, W.; Li, D.; Zheng, T.L. Research on water based coating for magnesium alloy. Adv. Mater. Res. 2006, 15-17, 485-490. [CrossRef] 